\title{
IMPACT OF YOUTH GUARANTEE INITIATIVES ON NEETS POPULATION CHANGES IN EU
}

\author{
Linas Stabingis \\ Assoc. prof. dr. Vytautas Magnus University, Universiteto str. 10-211, 53361 Akademija, Kaunas r., Phone \\ number. +370 377522 59, E-mail: linas.stabingis@vdu.lt
}

Received 1001 2020, Accepted 28052020

\begin{abstract}
An economic downfall, which started at the end of year 2008, had dramatic impact on increase of youth population from 15-24 aged group Not in Employment, Education or Training (NEET) in EU Member States. An identification of success factors driving positive changes in NEETs population by implementing Youth Guarantee (YG) initiatives in EU countries is the scientific problem analysed in this publication. The main purpose of investigation is identification of groups of EU countries according level of youth unemployment and the impact made by implementing the YG initiatives. The cluster analysis techniques is used and three groups of EU Member States revealded according both groups of indicators: a) the share of NEETs at start position of YG implementation and in year 2017; b) the share of NEETs attended YG and positive outcome in 6 month after compleating participation in this programme. Results of investigation show most progress reached those countries that have successfully developed public-private partnerships in process of implementation of YG programme.
\end{abstract}

Keywords: youth unemployment, NEETs, Youth Guarantee, clustering, cross-country comparison in $E U$.

JEL codes: I25, J64, J21.

\section{Introduction}

Many countries are dealing the problem of weak participation of young people in labour market. An economic downfall, which started at the end of year 2009, had dramatic impact on youth employment rate in the European Union and it reached an all-time low level of $32.9 \%$ in the first half of 2011 (Furlong, 2013). Due to that very important is search of new ways foreseeing possibilities to avoid loss of enthusiasm of youth on finding their place in labour market. European Commission (2016) underlined the need for Europe to strengthen its economic recovery and one measures, which could lead to success seeking this target is strong investment in youth and jobseekers.

An employment rates are steadily improving in EU countries in recent years, but any case approximately 3.3 million of young people from 15-24 age group still were registered as unemployed at the begining of year 2019. In addition, in year 2018 more than 5.5 million young people (aged 1524 years) were neither in employment nor in education or training (NEETs). The difference in employment rates EU member states is very high - more than 30 percent points. (European Commission, 2019)

Long-term exclusion from the labour market and education at young age is riskier than for representatives of any other age groups and may result in formation of lifelong barriers on future employment and earning prospects as well as self-confidence and quality of life. According Mascherini (2017), being excluded both from the labour market and education heightens the individual's risk of social exclusion and the probability of engagement into negative behaviour activities affecting both individual wellbeing and their relationship with society, including withdrawal from participation in democratic, civil and political processes.

Copyright (C) 2020. Published by Vytautas Magnus University. This is an open access article distributed under the terms of the Creative Commons Attribution Non-Commercial 4.0 (CC BY-NC 4.0) license, which permits unrestricted use, distribution, and reproduction in any medium provided the original author and source are credited. The material cannot be used for commercial purposes. 
Fighting youth unemployment about 9 million young people have benefitted from the EU Youth Guarantee. The main purpose of this framework is improvement school-to-work transitions, investment into young people's employability and prevention the risk of social exclusion. (European Commission, 2017a).

The reasons of increase of number of NEETs as consequence of economic downfall in almost all EU Member States as well as problems in "school-to-work" transition analysed in publications of following authors: Roberts (2011), Yates, et al. (2011), Cahuc, Carcillo, Rinne, et al. (2013), Bruno, Marelli, Signorelli, (2014), Eichhorst, Neder (2014), Tamesberger, Leitgöb, Bacher (2014), Escudero, Mourelo (2015), Maguire (2015), Dhéret and Roden (2016), Ferragina, Feyertag, SeeleibKaiser (2016), Caliendo, Künn, SMahlstedt (2017), Driouchi, Harkat (2017), Mascherini (2017, 2018), O'Reilly, et al. (2018).

Many authors agree the financial support is crucial important, but not enough measure for increase of youth employment. Seeking efficient use of support from EU and national level programs are need a lot of efforts this support should be more targeted on reaching an expectable result. Many scientific publications investigate in measures on youth employment increase by improving pathway from education to labours market, by providing more light on nowadays interests of employers and wishes of young people, by proposing ways to avoid conflicts among representatives from different generations, but less attention is paid on assessment of measures applied for youth inclusion into labour market or, at least, returning to education, training or apprenticeship.

An identification of success factors driving positive changes in NEETs population in EU countries is the scientific problem analysed in this publication. The main purpose of investigation is identification of groups of EU countries according level of youth unemployment and the impact made by implementing the Youth Guarantee iniciatives, to reveal the similarities and differences of intervention measures applied in particular countries to be reviled main success factors and identified problems has to be solved in the future.

The main tasks of research are:

1. To make an analysis of scientific publications and official documents on EU policies and measures targeted to decrease NEETs population and Youth unemployment;

2. To make clustering of EU countries according chosen indicators showing results in implementation of Youth Guarantee;

3. To make assessment of success factors in each cluster of countries included into investigation.

Seeking to detect EU countries types according success of YG implementation, cluster analysis techniques is used. The goal of which use is to find groups of EU Member States - that are most similar within clusters while being as dissimilar as possible across clusters. For this purpose, the hierarchical agglomerative clustering methods are employed. Use of these methods it was started out by specifying each included country as one individual cluster. The cluster approach then gradually combines Member States into clusters. The choice of the number of clusters need to be determined their similarities and dis-similarities. The Ward method is chosen as the way the clustering algorithm combines similar observations into clusters which are of similar importance. Seeking to choose the number of clusters to be generated, the Duda-Hart optimality criterion was applied. In case of investigation, the comparison is restricted to between two and five clusters and optimal value index is detected.

The empirical application follows a two-step procedure. In the first step, a cluster analysis for each empirical indicator was defined. In the second step, the main cluster analysis based on all indicators determines a final cluster analysis which allows analyse of their correspondence to the sub clusters from the first stage. As far as it was met difficulties to make clear interpretation of results were obtained, the variables used for investigation were divided into two groups. This decision allowed to make interpretation-friendly clustering of countries according their success in implementation of $\mathrm{YG}$ initiatives. 


\section{Reserch results and discussions}

First real step toward strengthening labour market in EU countries it was made in March 2000 when the European Council set out a ten-year strategy which aimed to make the Union "the most competitive and dynamic knowledge-based economy in the world, capable to deliver sustainable economic growth with more and better jobs and greater social cohesion" and set means of specific indicators have be achieved by 2010 (Rodriguez, 2010). Unfortunately, global economic downturn which started in year 2009 not allowed to reach foreseen target and almost all the progress achieved since the approval of the strategy was lost.

The economic downturn was followed by decrease of total employment level and especially among youth under age of 25. The Member States of the EU dealt challengers not only in speeding up in recovery of economics, but and in motivating young people to seek an employment, education or training to prepare themselves for participation in the labour market. As it was stated in report written by Caliendo, Künn and Mahlstedt (2018), facing nowadays problems are necessary changes in the world of work which may further impede the labour market prospects among young people, for example, increase number of problematic cases of school-to-work transitions and new challenges arising from rapid technological progress.

The main task of the policies oriented to economic growth promotion and social equity ensuring is creation of conditions young people should be adequately educated, their transition to the labour market should be smooth and their participation in the labour market should be sustainable through all their lifetime in employment.

It is very important to stress out that problems in youth unemployment and inactivity appeared before the economic downturn started. Quintini et al. (2007) already before the beginning of economic recession stated young people face a wide range of structural challenges - frequently perceived as increasingly complex and connected with problems in school-to-work transition process and indeterminacy of long-term labour market perspectives. Dealing challengers of economic recovery, companies concentrated on maximisation of performance even more than in previous phases of their operations and tend to employ highly experienced professionals, whose supply become higher in this period of time. This situation affected the level of demand for young people and limited employers' absorption capacities in providing jobs, training and apprenticeships places for young people (Eurofound, 2015). Due to that young people more frequently could find themselves as labour market 'outsiders' in comparison to their older counterparts as well as due to lower probability access the permanent contracts with high levels of workers' rights protection including shorter notice periods and reduced severance payment (European Parliament, 2015; European Commission, 2018a).

Greet challenge, which is facing youth, is labour market segmentation. This resulted young people particularly involuntary had to agree be involved in part-time, casual, a-typical or precarious work on temporary or part-time contracts. (European Commission, 2017b)

According Caliendo, Künn and Mahlstedt (2018), there are several reasons due to which dramatically raised youth unemployment and increased NEETs population during the recession in most EU countries:

a) Prolonged, complicated, unstable, and non-linear studies-to-work transitions;

b) Deterioration in the quality of youth employment and increase of precariousness;

c) Week availability of quality work experience, which had a crucial negative impact on success in studies-to-work transitions;

d) Increase of youth inactivity, ignorance of labour market realities and detachment from them;

e) Greater labour market unfriendliness for disadvantaged young people - i.e. low-skilled, migrants and those with a disability.

In addition, the Report on Public Employment Service Implementation of the Youth Guarantee payed attention to (European Commission, 2017b):

1) Imperfectly functioning education and training systems with poor outcomes and mismatched skills; 
2) Segmented labour markets, influencing skills polarisation;

3) Poor Public Employment Service, in general not allowing provision of the youth-related tailored services;

4) Attempts to concentrate the disposable resources only on vulnerable, hard-to-reach young people, in particular, including certain sub-groups of NEETs.

Possible negative consequences of youth unemployment and inactivity could be very painful for both - youth and society. Ferragina et al. (2016) stated that one of the most possible dramatic consequences of this growing divergence could be explained by the disenfranchisement of labour market outsiders, especially young people, from social and political participation. In addition, unsatisfactory early labour market experience, long-lasting and complicate studies-to-work transitions can lead to negative long-term effects on young people life threw reduced earnings, increased probability of further periods of short or long-term unemployment and complications in returning an employment after these periods (Gregg and Tominey, 2005) as well as poor health and well-being (Scarpetta et al, 2010).

Seeking to solve the problem of youth inactivity and increase of NEETs inclusion there were made efforts to reform or strengthen education and training systems at resent years, including improvement of vocational education and training combining it with apprenticeships, applied other educational measures aimed to bring back to education and training young people with low levels of skills and competences. We need to ensure that the education and training systems should be able to equipped young people with relevant professional knowledge and skills actual in dynamic environment as well as to develop personal features such as adaptability, resilience and ability of own career management. According Caliendo, Künn and Mahlstedt (2018), an apprenticeship involves inclass education together with on-the-job training and could play important role in studies-to-work transitions. Unfortunately, only in few countries across EU - i.e. Germany, Austria and Denmark, amount of young people who undertake an apprenticeship is above $5 \%$, but in all other EU countries this indicator is below $1.5 \%$.

Advanced idea for decrease of NEETs population come from the Nordic countries, where initiatives, targeted to solve this problem, have been first implemented in year 1984 in Sweden and later on in year 1996 in Denmark and Finland (Escudero and Mourelo, 2017). The essence of these initiatives it was introduction of structural reforms to modernise overall labour market policies focusing on support for young people. The aim of such reforms was improvement the functioning of the labour market by rethinking institutional and regulatory framework, allowing reaching better matching of demand and supply (Caliendo, Künn and Mahlstedt, 2018). A similar initiative, titled as a Youth Guarantee programme, in EU level adopted by the Council in April 2013 in response to unprecedented levels of youth unemployment, which raised until $23.5 \%$ in average across EU at the end of 2012 and in some countries increased by more than 50\% (Escudero, Mourelo, 2015). The European Youth Guarantee could be valuated as the commitment of EU Member States to ensure that all young people should receive an offer, suited to their abilities and experiences, for employment, training, apprenticeship or continued education within four months after becoming unemployed or leaving formal education. (Council of the European Union, 2013).

The Council not only initiated start of Youth Guarantee programme, but also recommended member states to implement the following labour market-related measure (Council Recommendations, 2013): a) to reduce the non-wage labour costs where it is possible in order to stimulate young people's possibilities for recruitment; b) to promote labour mobility for young people and to create possibilities to receive information about the job offers, traineeships and apprenticeships as well as an available support in different areas, regions or countries; c) to create more services for start-up support and coordination of activities between employment providers and business support services to increase awareness of the possible chances and perspectives for self-employment.

It is very important to stress the Youth Guarantee is not a source for funding by itself. It is a political commitment of EU and Member States to provide financial contributions from the EU and national budgets and to attract financing as well as involve into implementation the private and non- 
profit institutions. There were foreseen following channels for the funding of the Youth Guarantee implementation (Caliendo, Künn and Mahlstedt, 2018):

1) Youth Employment Initiative (YEI), support from which could be delivered for young people aged 16-25 who are not in employment, education or training and who are living only to regions where youth unemployment was higher than $25 \%$ in year 2012;

2) European Social Fund (ESF) for support of structural reforms and implementation of further employment-related programmes directly or indirectly benefiting youth without requirement to focus specifically only on NEETs;

3) Other EU sources, for example, European Regional Development Fund (ERDF), the ERASMUS programme and the European Globalisation Adjustment Fund (EGF), which could provide the support for employment-related and education-related programmes in Member States.

As a European Court of Auditors highlighted in their report, the YEI/ESF funding covers only a small part of the required amount of support for the implementation of Youth Guarantee measures. Therefore, Member States need to find out significant additional resources from national budgets and other public and private sources to achieve foreseen goals of this programme (European Court of Auditors, 2017).

Assessment of the progress of EU countries in implementing YG is a complex task for a number of reasons, including different levels of particular country economic development, different levels of overall and youth unemployment in each country, differences in the evolution and present situation of education systems, cultural traditions and business development experiences. In addition, the objectives of the program are known, but there are no clear criteria for reliably measuring progress in this area. It would be naive to expect that youth activity and inclusion into labour market could increase at the same rate over few years in all EU countries. Therefore, the following indicators sets were chosen for YG impact assessment:

1. Percentage of NEETs aged 15-24 in comparison with the total youth of this age in year 2013 .

2. Level of NEETs aged 15-24 in percent at the end of the year 2017 in comparison with the year 2013.

3. Percentage of NEETs aged 15-24, who first time were involved in YG activities in period 2014-2017. This indicator does not include those NEETs, who repeatedly were involved in activities of YG program after some time.

4. Positive outcome in 6 month after completing participation in YG in period 2014-2017 - i.e. young people aged 15-24 were involved into labour market, education or training in 6 month period after completing participation in YG.

The data used for investigation are received from officialy published sources such as Eurostat as well as reports on progress in YG implementation from particular countries (European Commission (2018b) and presented in table 1.

According the share of NEETs aged 15-24 in comparison with total youth population of this age (shown in table 1), EU countries preliminary were splited into three groups. The first group include countries with less or $10 \%$ of inactive youth in comparison with the total number of young people in this age group, the second group include countries with more than $10 \%$ and less or $15 \%$ of young people in this age group and the third group include countries in which share of inactive youth is more than $15 \%$.

According the percentage of NEETs aged 15-24, who first time were involved in YG activities in period 2014-2017 (shown in table 1), EU countries preliminary were split into three groups. The first group include countries with less or $40 \%$ of NEETs of this age. The second group include countries with more than 40 and less or $75 \%$ of NEETs of this age and the third group - countries in which share of involved NEETs is more than 75\%, including case of Luxembourg with $100 \%$ of involvement.

According the percentage of NEETs with positive outcome in 6 month after completing participation in YG (shown in table 1), EU countries preliminary were split into three groups also. The first group include countries with positive outcome less or equal to $50 \%$, the second group include 
countries with positive outcome higher than $50 \%$ and less or equal to $75 \%$ and the third group include countries in which the level of positive outcome equal $75 \%$ and above.

According the level of NEETs aged 15-24 at the end of the year 2017 in comparison with the year 2013 (shown in table 1), EU countries were split into two groups: a) countries in which level of NEETs decreased in this period of time and $b$ ) countries in which level of NEETs not changed or, unfortunately, increased despite all the efforts of those countries.

Table 1. The indicators used for cluster analysis seeking to identify EU Member States groups according percentage of NEETs aged 15-24 and results of implementation of YG activities in period of time 2014-2017

\begin{tabular}{|c|c|c|c|c|c|c|}
\hline \multirow{2}{*}{\multicolumn{2}{|c|}{ Country's }} & \multirow{2}{*}{\multicolumn{2}{|c|}{$\begin{array}{l}\text { Percentage of NEETs } \\
\text { population aged } 15-24 \text { in } \\
\text { comparison with the } \\
\text { total youth of this age, } \%\end{array}$}} & \multirow{3}{*}{$\begin{array}{l}\text { Level of } \\
\text { NEETs at the } \\
\text { end of } 2017 \\
\text { in comparison } \\
\text { with } 2013, \%\end{array}$} & \multicolumn{2}{|c|}{$\begin{array}{l}\text { Percentage of NEETs } \\
\text { population aged } 15-24 \text { in year } \\
2014-2017, \%\end{array}$} \\
\hline & & & & & \multirow{2}{*}{$\begin{array}{l}\text { Partici- } \\
\text { pated in } \\
\text { YG }\end{array}$} & \multirow{2}{*}{$\begin{array}{l}\text { positive } \\
\text { outcome after } \\
\text { completing YG }\end{array}$} \\
\hline title & $\begin{array}{l}\text { acro- } \\
\text { nym }\end{array}$ & $\begin{array}{l}\text { in year } \\
2013\end{array}$ & $\begin{array}{l}\text { in year } \\
2017\end{array}$ & & & \\
\hline Belgium & $\mathrm{BE}$ & 12.7 & 9.3 & 73.2 & 46.9 & 75.3 \\
\hline Bulgaria & BG & 21.6 & 15.3 & 70.8 & 85.2 & 61.3 \\
\hline $\begin{array}{l}\text { Czech } \\
\text { Republic }\end{array}$ & $\mathrm{CZ}$ & 9.1 & 6.3 & 69.2 & 53.5 & 68.1 \\
\hline Denmark & DK & 6.0 & 7.0 & $1.0 / 116.7$ & 73.2 & 81.0 \\
\hline Germany & $\mathrm{DE}$ & 6.3 & 6.3 & 0.0 & 63.2 & 71.6 \\
\hline Estonia & $\mathrm{EE}$ & 11.3 & 9.4 & 83.2 & 50.5 & 68.3 \\
\hline Ireland & $\mathrm{IE}$ & 16.4 & 10.9 & 66.5 & 58.6 & 78.0 \\
\hline Greece & EL & 20.4 & 15.3 & 75.0 & 73.3 & 54.3 \\
\hline Spain & ES & 18.6 & 13.3 & 71.5 & 56.6 & 99.5 \\
\hline France & FR & 11.2 & 11.5 & 102.7 & 27.4 & 62.4 \\
\hline Croatia & HR & 19.6 & 15.4 & 78.6 & 59.7 & 66.7 \\
\hline Italy & IT & 22.2 & 20.1 & 90.5 & 96.8 & 98.2 \\
\hline Cyprus & $\mathrm{CY}$ & 18.7 & 16.1 & 86.1 & 35.4 & 33.5 \\
\hline Latvia & $\mathrm{LV}$ & 13.0 & 10.3 & 79.2 & 69.7 & 75.5 \\
\hline Lithuania & LT & 11.1 & 9.1 & 82.0 & 67.7 & 60.0 \\
\hline Luxembourg & LU & 5.0 & 5.9 & 118.0 & 100.0 & 69.3 \\
\hline Hungary & $\mathrm{HU}$ & 15.5 & 11.0 & 71.0 & 89.1 & 95.6 \\
\hline Malta & MT & 9.9 & 8.6 & 86.9 & 90.2 & 79.1 \\
\hline Netherlands & $\mathrm{NL}$ & 5.6 & 4.0 & 71.4 & 40.3 & 72.1 \\
\hline Austria & $\mathrm{AT}$ & 7.3 & 6.5 & 89.0 & 26.2 & 68.1 \\
\hline Poland & PL & 12.2 & 9.5 & 77.9 & 56.3 & 64.4 \\
\hline Portugal & $\mathrm{PT}$ & 14.1 & 9.3 & 66.0 & 56.3 & 64.4 \\
\hline Romania & $\mathrm{RO}$ & 17.0 & 15.2 & 89.4 & 14.9 & 46.5 \\
\hline Slovenia & SI & 9.2 & 6.5 & 70.7 & 65.7 & 74.1 \\
\hline Slovakia & SK & 13.7 & 12.1 & 88.3 & 59.9 & 72.3 \\
\hline Finland & FI & 9.3 & 9.4 & 101.1 & 46.1 & 69.7 \\
\hline Sweden & $\mathrm{SE}$ & 7.5 & 6.2 & 82.7 & 53.2 & 69.9 \\
\hline $\begin{array}{l}\text { United } \\
\text { Kingdom }\end{array}$ & UK & 13.2 & 10.3 & 78.0 & 18.9 & 37.4 \\
\hline
\end{tabular}

Source: developed by author using Eurostat and European Commission data

Cluster analysis based on use of all chosen indicators allowed see their correspondence to the sub clusters from the first stage. There were determined two clusters (optimal meaning of value index 
equal 0.5456), first of which covers 23 countries (IT, HU, LU, MT, EE, CZ, SE, NL, BE, FI, IE, SK, HR, PL, PT, BG, EL, LT, ES, DK, LV, DE, SI) and the second - 5 countries (FR, AT, CY, RO, UK). Cluster dendrogram of this investigation presented in the Figure 1. Average meanings of indicators in the first and the second cluster are respectively: a) 12.62174 and 13.48 for indicator „Percentage of NEETs aged 15-24 in comparison with the total youth of this age in year 2013“; b) 68.1 and 71.4 for indicator „Level of NEETs aged 15-24 at the end of the year 2017 in comparison with the year 2013 “; c) 65.739 and 24.56 for indicator „Percentage of NEETs aged 15-24, who first time were involved in YG activities in period 2014-2017“ as well as d) 73.42 and 49.56 for indicator „Positive outcome in 6 month after completing participation in YG in period 2014-2017“. Unfortunately, the obtained result hampered the interpretability of results even on sub clusters level.

Seeking to provide an interpretation-friendly cluster analysis, the variables used for investigation, were divided into two groups. The first group included indicators reflecting the baseline of NEETs in year 2013 and level of NEETs in percent at the end of the year 2017 in comparison with the year 2013. The second group included indicators reflecting the percentage of NEETs who first time were involved in YG activities in period 2014-2017 and the share of participants of YG with positive outcome in 6 month after completing participation in this programme at the same period of time.

Seeking to reveal similarities and differences of EU Member States according the share of NEETs at start position of YG implementation in year 2013 and the level of NEETs at the end of the year 2017 in comparison with the year 2013 in percent, the cluster analysis of first two indicators defined before is conducted. Cluster dendrogram of this investigation presented in the Figure 2. This investigation as optimal reviled three clusters, first of which covers 10 countries, the second -13 countries and the third -5 countries.

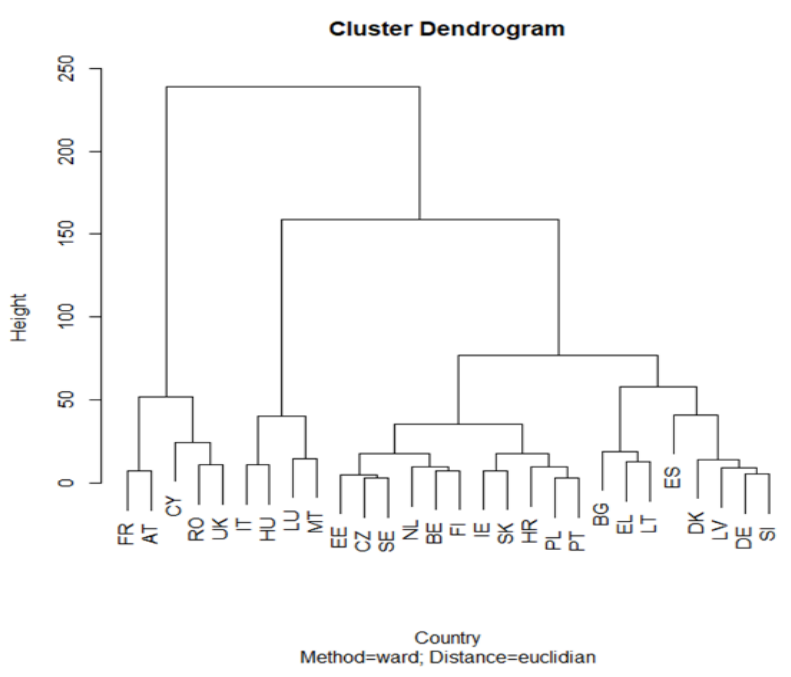

Figure 1. Cluster dendrogram of EU Member States participated in YG programme according all indicators used for investigation

The first cluster (let's call it as cluster A) include countries (IT, CY, RO, PT, IE, HU, BG, ES, EL, HR), in which indicator „Percentage of NEETs aged 15-24 in comparison with the total youth of this age in year 2013“ is highest among EU Member States and varies in an interval from 14.1\% to $22.2 \%$ with average meaning of $18.41 \%$ as well as decrease of number of NEETs until the end of year 2017 variate from $70.83 \%$ in Bulgaria until 89.41\% in Romania with average meaning equal to $79.36 \%$. To make it easier the description of this cluster in the text of the article, let's call it as cluster A. Most of the countries included into this cluster are located at the southern part of Europe, not depending on time they joined EU and slightly depending on level of economic development. Also, high unemployment rates are common for citizens of all age groups in these countries (European 
Commission, 2018b). Progress in decrease of share of NEETs population is clearly seen in analysed period of time, but does not guarantee a major breakthrough in reducing the number of youth who are not in employement, education or training.

The second cluster (let's call it as cluster B) includes countries (BE, PL, LV, UK, SK, MT, EE, LT, AT, SE, NL, CZ, SI), in which indicator „Percentage of NEETs aged 15-24 in comparison with the total youth of this age in year 2013“ varies in relatively wide interval from $5.6 \%$ in Netherland until $13.7 \%$ in Slovakia with average meaning of this indicator equal to $10.446 \%$ inside of cluster as well as decrease of the number of NEETs variate from $73.228 \%$ in Belgium until 89.041\% in Poland at the end of year 2017 (average meaning is 76.53\%). Some of countries included into this cluster are located in the Western, some in Eastern Europe, but their inclusion into this cluster has no correlation with level of economic development or the deepness its downturn at the end of 2008. The relative decline in the share of NEETs in the countries of this cluster is almost the same as in the countries belonging to the cluster A.

The third cluster (let's call it as cluster C) include countries (DK, LU, DE, FR, FI), in which are relatively lowest meanings of indicator „Percentage of NEETs aged 15-24 in comparison with the total youth of this age in year 2013“, which varies in the interval from 5.0\% in Luxembourg until $11.2 \%$ in France with average meaning of this indicator equal to $7.56 \%$. The share of NEETs in this group of countries not changed until the end of year 2017 (in Germany) or even increased by 18.0\% in Luxembourg (average meaning of increase of number of NEETs in these countries is $7.68 \%$ ). These countries are the EU's leaders in terms of the level of economic development, with relatively little impact from the economic downturn at the end of 2008.

The reason why share of NEETs increased in these countries are not clear looking even at the percentage of the NEETs participated in YG activities with exception of France, in which there were involved only $27.4 \%$ of NEETs and partly of Finland where level of participation in YG was equal to $46.1 \%$.

Seeking to reveal similarities and differences of EU Member States in share of NEETs attended YG programme for first time in period 2014-2017 and positive outcome in 6 month after completing participation in this programme at the same period of time, an indicator "Percentage of NEETs aged 15-24, who first time were involved in YG activities in period 2014-2017" and indicator „Positive outcome in 6 month after completing participation in YG in period 2014-2017“ there were used. Cluster dendrogram of this investigation is presented in the Figure 3. Optimal number of clusters in this case also are three, first of which covers 19 countries (DK, LV, SI, BG, EL, LT, ES, NL, BE, FI, IE, DE, SK, EE, CZ, SE, HR, PL, PT), the second - 4 countries (IT, HU, LU, MT) and the third -5 countries (FR, AT, CY, RO, UK).

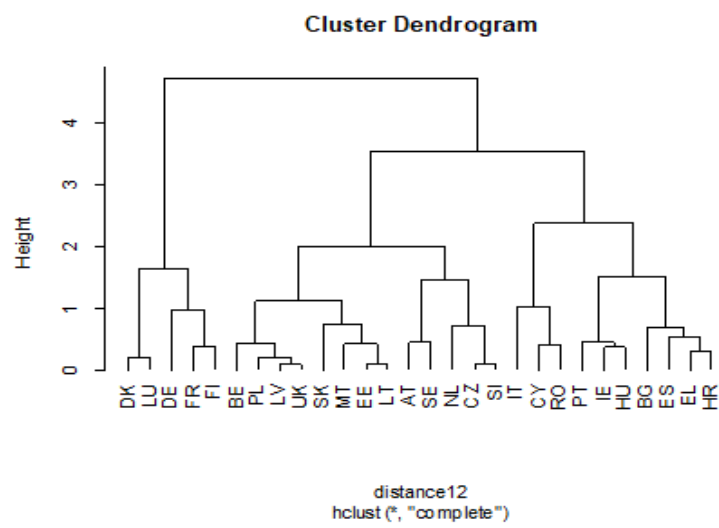

Figure 2. Cluster dendrogram of EU Member States which participated in YG programme according the level of NEETs aged 15-24 in year 2013 and the level of NEETs in percent at the end of the year 2017 in comparison with the year 2013

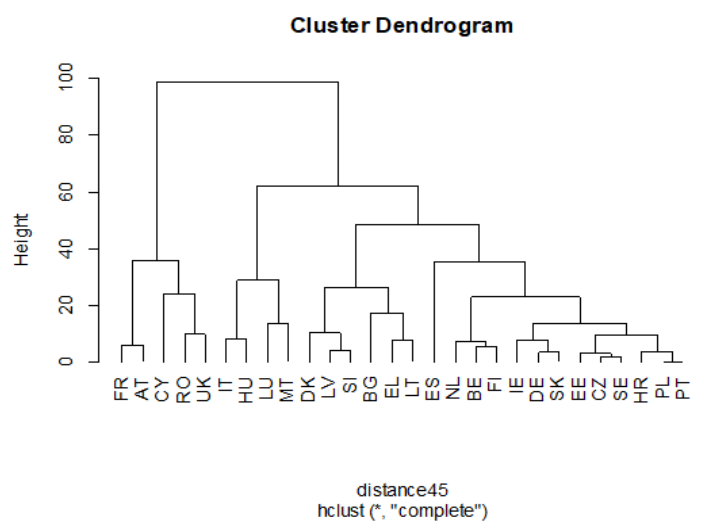

Figure 3. Cluster dendrogram of EU Member States according the share of NEETs attended YG programme for first time in period 20142017 and positive outcome in 6 month after completing participation in this programme at the same period of time 
The first cluster from this investigation (let's call it as cluster D) include most part of EU Member States (DK, LV, SI, BG, EL, LT, ES, NL, BE, FI, IE, DE, SK, EE, CZ, SE, HR, PL, PT). An indicator ,Percentage of NEETs aged 15-24, who first time were involved in YG activities in period 2014-2017“ has very wide range of variation from $40.3 \%$ in Netherland until $85.2 \%$ in Bulgaria with average meaning of $59.784 \%$ as well as indicator „Positive outcome in 6 month after completing participation in YG in period 2014-2017“" variate from 54.3\% in Greece until 99.5\% in Spain with average meaning of $70.868 \%$. Countries of this cluster are scattered across Europe and differ in terms of their level of economic development, duration of EU membership, number of population and overall level of unemployment. It is very important to stress relatively high level of positive outcome (more than 50\%) in 6 month after completing participation in YG and a significant impact on the decline in NEETs population.

The second cluster from this investigation (let's call it as cluster E) include only four countries (IT, HU, LU, MT), in which an indicator „Percentage of NEETs aged 15-24, who first time were involved in YG activities in period $2014-2017^{\text {“ }}$ variate from $89.1 \%$ in Hungary until $100 \%$ in Luxembourg with average meaning of $94.025 \%$ as well as indicator „Positive outcome in 6 month after completing participation in YG in period 2014-2017“ variate from 69.3\% in Luxembourg until $98.2 \%$ in Italy with average meaning of $85.55 \%$. Very high share of NEETs who were involved in YG activities and high level of positive outcome in 6 month after completing participation in YG promotes the belief that a major breakthrough has been achieved in solving of youth unemployment in countries of this cluster, but data on reduction of NEETs population (table 1) do not show this, especially in Hungary, where the percentage of NEETs declined from $15.5 \%$ until $11.0 \%$ in period of time from 2014 until 2017, and in Italy, where the percentage of NEETs declined only from 22.2\% until $20.1 \%$ at the same period of time. The reasons of this phenomenon are unclear and require deeper investigation.

The third cluster from this investigation (let's call it as cluster F) include five countries (IT, HU, LU, MT), in which an indicator ,Percentage of NEETs aged 15-24, who first time were involved in YG activities in period 2014-2017“ variate from 14.9\% in Romania until 35.4\% in Cyprus with average meaning of $24.56 \%$ as well as indicator „Positive outcome in 6 month after completing participation in YG in period 2014-2017“ variate from 33.5\% in Cyprus until $68.1 \%$ in Austria with average meaning of $49.58 \%$. This group of countries could be characterised as having very low level of NEETs involvement into YG and having weak outcome in 6 month after completing participation in this programme.

The list of countries included into this cluster is exactly the same as the list of countries in cluster $\mathrm{C}$. Taking into consideration the fact these countries has relatively low level of NEETs, low attention of these countries for implementation of YG is understandable, but unjustifiable because it not affected on decrease of NEETs population or, at least, influenced increase of this indicator in some countries.

\section{Conclusions and policy recommendations}

The launch of the European Youth Guarantee raised great attention among stakeholders in Europe. This happened due several reasons: a) an innovative view on ways unemployment and inactivity of youth, especially those who depend to age group from 15 to 25 ; b) this measure arrived in a moment when high youth unemployment levels that had persisted in the region since the economic downturn in 2008 required an urgent response. Commitment of EU Member States' to ensuring that young NEETs should receive a good continued education and employment, training or apprenticeship opportunity within a psychologically acceptable period of time seems as an appropriate political response to this very serious problem. Looking at the seriousness and the magnitude of this problem from nowadays perspective, the implementation of such programme it should have be launched few years early. 
The different commitments outlined in the YG scheme have been implemented in practice. A regular analysis of the results achieved shall be carried out in order to identify the advantages and disadvantages of implementing this program and to suggest improvements of measures are taken. Various statistical data are regularly collected and published reflecting the results of YG implementation, official reports on the progress made are drawn up and published by the EU Member States. However, there is a significant lack of research reflecting the impact of different decisions on the scale of achievement and the rational use of allocated funds.

An analysis of statistical data and reports presented by particular countries (European Commission, 2018b) allow to make conclusion that the implementation of the YG scheme is a welcome initiative, especially in terms of the actions were planed and implemented. The implementation process is still underway. The majority of European countries have already applied many measures towards the establishment of this programme. Investigation into plans prepared by particular European countries and presented in annual reports reveals a wide spectrum of measures which they are going to implement within the framework of the YG. The plans of majority of countries include most elements recommended by Council: a) preparation of the programmes focussed on improvement of education and training for more successful transition from education to employment; b) intensive work on initiatives to reduce school dropout and provide possibilities for remedial education; c) creation of services for employment intermediation; d) developement specific measures targeting the most vulnerable young people according clear eligibility criteria.

Analysis of the data provided in the reports presented by particular countries allow to conclude the measures, suggested by European Commission, have produced significant change and yielded positive results where these measures were designed and implemented properly, taking into consideration real situation, youth and employers wishes.

Moreover, social dialogue and participation of all social partners in planning, implementation, execution and monitoring of measures has very important role on the way to success. Analysis of reports from various EU Member States (European Commission, 2018b), especially those with greeter success show that most countries concentrated on the partnership approach while implementing Youth Guarantee programme and established cooperation with participation among employers' organizations, trade unions, schools and training centres and non-governmental organizations. But, as Dhéret and Roden (2016) rightly observed, most cases cooperation between ministries and other governmental institutions, dealing employment and educational policies, it was foreseen and less frequently the cooperation with Non-Governmental Organisations, social partners and youth organisations was established.

The European Court of Auditors as one of the risks factors on successful implementation of the Youth Guarantee highlighted the fact $60 \%$ of countries analysed have submitted proposed expenditures in their implementation plans below the recommended levels (European Court of Auditors, 2015). These countries need to make greater financial commitments in order to meet their target of reducing youth unemployment. However, some countries allocated more funds for implementation of YG program in comparison with official recommendation. One of the countries that have done this is Ireland, in which the share of NEETs declined from $16.4 \%$ to $10.9 \%$ until the end of 2017 and this is one of the best results among EU countries.

The challengers, which EU member States deal in reducing youth unemployment and decreasing NEETs population, are very serious and complicated. No one can say exactly what needs to be done to get things done quickly and reliably. This investigation provided more light on success of YG implementation processes, on countries whose success is greater than others. This investigation provides an opportunity to focus on the credibility of the countries that have made the most progress in implementation of YG. Especially positive is sharing experiences with other countries, even those with significantly lower achievements, understanding that the expectations of societies in these countries, believable, are the same as in countries which succeed. Any case more detailed investigation is needed to assess the efficiency of spendings focusing on public-sector and privatesector partnerships in particular countries for more successful youth involvement into the labour 
market as a guarantee for the success of EU economic and sustainable social development, especially in countries with high rates of long-term youth unemployment.

\section{References}

Bruno, G.S., Marelli, E., Signorelli, M. (2014). The Rise of NEET and Youth Unemployment in EU Regions after the Crisis // Comparative Economic Studies. Vol. 56: 592-615. https://link.springer.com/article/10.1057/ces.2014.27 [2019 11 24].

Cahuc, P., Carcillo, S., Rinne, U., et al. (2013). Youth unemployment in old Europe: the polar cases of France and Germany. IZA Journal of European Labor Studies. Vol.2. No.18. https://doi.org/10.1186/2193-9012-2-18 [2019 11 20].

Caliendo, M., Künn, S., Mahlstedt, R. (2017). Mobility Assistance Programmes for Unemployed Workers, Job Search Behaviour and Labour Market Outcomes: IZA Discussion Papers. Institute of Labor Economics (IZA). - https://ideas.repec.org/p/iza/izadps/dp11169.html [2019 08 22].

Council of the European Union (2013). Council Recommendation of 22 April 2013 on establishing a Youth Guarantee. (2013). Official Journal of the European Union 26.4.2013, Brussels. - https://eurlex.europa.eu/legal-content/EN/ALL/?uri=CELEX:32013H0426(01) [2019 11 24].

Dhéret, C. and Roden, J. (2016). Towards a Europeanisation of Youth Employment Policies? - A Comparative Analysis of Regional Youth Guarantee Policy Designs, EPC Issue Paper N ${ }^{\circ} 81$. http://aei.pitt.edu/80224/1/pub_6949_towardseuropeanisationyouthemploymentpolicies.pdf [2019 0808 ].

Driouchi, A., Harkat, T. (2017). NEET Policies and Knowledge in Arab \& East Central European Economies. - MPRA Paper No. 80471, posted 30 Jul 2017. - https://mpra.ub.uni-muenchen.de/80471/ [2019 $1216]$.

Eichhorst, W., Neder, F. (2014). Youth Unemployment in Mediterranean Countries // IZA Policy Paper. No. 80, Institute for the Study of Labor (IZA), Bonn. - http://hdl.handle.net/10419/97185 [2019 12 06].

Escudero, V., Mourelo, E. L. (2015). The Youth Guarantee programme in Europe: Features, implementation and challenges: Research Department Working Paper. ILO, Geneva. https://www.ilo.org/wcmsp5/groups/public/---dgreports/---inst/documents/publication/wcms_393024.pdf [2019 08 05].

Eurofound (2015). Beyond the Youth Guarantee - Lessons Learned in the First Year of Implementation. (2015). Publications Office of the European Union, Luxembourg. http://www.eu2015lu.eu/fr/actualites/notes-fond/2015/07/info-epsco-documents/WL_Beyond-the-YouthGuarantee_Eurofound---June-2015_EN.pdf [2019 1124$]$.

European Commision (2019). EU factsheet on the Youth Guarantee and the Youth Employment Initiative. - https://ec.europa.eu/social/main.jsp?langId=en\&catId=1036 [2019 08 06].

European Commission (2018a). Data on national commitments regarding the European Alliance for Apprenticeships. - http://ec.europa.eu/social/main.jsp?catId=1148\&langId=en [2019 08 06].

European Commission (2018b). Data collection for monitoring Youth Guarantee schemes 2017. -

https://ec.europa.eu/social/main.jsp?catId=1143\&langId=en\#YGIF [2019 08 07].

European Commission (2017a). 2018 European Semester: Annual Growth Survey. https://ec.europa.eu/info/publications/2018-european-semester-annual-growth-survey_en [2019 08 07].

European Commission (2017b). Report on PES Implementation of the Youth Guarantee. https://ec.europa.eu/social/BlobServlet?docId=18901\&langId=en [2019 08 09].

European Commission (2016). 2017 European Semester: Annual Growth Survey. https://ec.europa.eu/info/publications/2017-european-semester-annual-growth-survey_en [2019 10 14].

European Court of Auditors (2015). Young and unemployed in Europe: obstacles ahead for the EU's Youth Guarantee, Luxembourg: Press Release.

https://www.eca.europa.eu/en/Pages/NewsItem.aspx?nid=5715 [2019 10 14].

European Court of Auditors (2017). Youth unemployment - have EU policies made a dif-ference? An assessment of the Youth Guarantee and the Youth Employment Initiative https://eca.europa.eu/Lists/ECADocuments/SR17_5/SR_YOUTH_GUARANTEE_EN.pdf

European Parliament (2015). Differential Treatment of Workers under 25 with a view to their Access to the Labour Market.

http://www.europarl.europa.eu/thinktank/en/document.html?reference=IPOL_STU(2015)536299 [2019 10 23]. 
Ferragina, E., Feyertag, J., Seeleib-Kaiser, M. (2016). Outsiderness and participation in liberal market economies. The Open Journal of Socio-Political Studies, Vol. 9, No 3: 986-1014. https://core.ac.uk/display/80777839 [2019 07 16].

Furlong, A. (2013). Youth Studies: An Introduction. Abingdon: Routledge. 300 p. https://books.google.lt/books?id=Ij2iyrr6t-EC\&hl=lt [2019 07 24].

Gregg, P., Tominey, E. (2005). The wage scar from male youth unemployment, Labour Economics. Vol. 12, I 4: 487-509. [2019 07 15].

Maguire, S. (2015). Young people not in education, employment or training (NEET): Recent policy initiatives in England and their effects // Research in Comparative \& International Education. Vol. 10. No. 4: 525-536. - https://journals.sagepub.com/doi/full/10.1177/1745499915612186 [2019 11 20].

Mascherini, M. (2017). Good Practices in Dealing with Young People Who Are NEETs: Policy Responses at European Level: Presentation at the conference. Towards a Participatory Society: New Roars to Social and Cultural Integration. 1-2 May 2017. Vatican City. http://www.pass.va/content/scienzesociali/en/publications/acta/participatorysociety/mascherini.html [2019 12 12].

Mascherini, M. (2018). Origins and future of the concept of NEETs in the European policy agenda. Published to Oxford Scholarship Online: 2019. https://www.oxfordscholarship.com/view/10.1093/oso/9780190864798.001.0001/oso-9780190864798chapter-17 [2019 1218$]$.

O'Reilly, J., et al. (2018). Youth Labor in Transition: Inequalities, Mobility, and Policies in Europe. Published to Oxford Scholarship 2019.

https://www.oxfordscholarship.com/view/10.1093/oso/9780190864798.001.0001/oso-9780190864798 [2019 $1204]$.

Quintini, G., Martin, J. P., Martin, S. (2007). The Changing Nature of the School-to-Work Transition Process in OECD Countries. WDA-HSG Discussion Paper. http://www.oecd.org/employment/emp/38187773.pdf [2019 07 25].

Roberts, S. (2011). Beyond „NEET“ and „tidy“ pathways: Considering the „missing middle“ of youth transition studies // Journal of Youth Studies. Vol.14. No.1: 21-39. https://www.researchgate.net/publication/263449234_Beyond_\%27NEET\%27_and_\%27tidy\%27_pathways _considering_the_\%27missing_middle\%27_of_youth_transition_studies [2020 0104 ].

Rodriguez, R. (2010). The Lisbon Strategy $2000-2010$. An analysis and evaluation of the methods used and results achieved: Final Report.

http://www.europarl.europa.eu/document/activities/cont/201107/20110718ATT24270/20110718ATT24270E N.pdf [2019 08 12].

Scarpetta, S., Sonnet A., Manfredi, T. (2010). Rising Youth Unemployment During The Crisis: How to Prevent Negative Long-term Consequences on a Generation?, OECD Social, Employment and Migration Working Papers. - https://www.oecd-ilibrary.org/social-issues-migration-health/rising-youth-unemploymentduring-the-crisis_5kmh79zb2mmv-en [2019 08 20].

Tamesberger, D., Leitgöb, H., Bacher, J. (2014). How to Combat NEET? Evidence from Austria // Intereconomics: Review of European Economic Policy. Vol. 49. No. 4:221-227. https://www.intereconomics.eu/pdf-download/year/2014/number/4/article/how-to-combat-neet-evidencefrom-austria.html [2019 12 10].

Yates, S., et al. (2011). Early occupational aspirations and fractured transitions: A study of entry into 'NEET' status in the UK. Journal of Social Policy. Vol.40. No.3: 513-534. https://pdfs.semanticscholar.org/fb34/695b43dc2f4fdc0c0f78a19e9b079c05e85d.pdf [2020 01 04]. 